\title{
Hibiscus chlorotic ringspot virus Coat Protein Upregulates Sulfur Metabolism Genes for Enhanced Pathogen Defense
}

\author{
Ruimin Gao, ${ }^{1}$ Florence Kai Lin Ng, ${ }^{1}$ Peng Liu, ${ }^{2}$ and Sek-Man Wong ${ }^{1,2}$ \\ ${ }^{1}$ Department of Biological Sciences, National University of Singapore, 117543, Singapore; ${ }^{2}$ Temasek Life Sciences Laboratory, \\ 1 Research Link, 117604, Singapore
}

Submitted 16 August 2012. Accepted 28 August 2012.

\begin{abstract}
In both Hibiscus chlorotic ringspot virus (HCRSV)-infected and HCRSV coat protein (CP) agroinfiltrated plant leaves, we showed that sulfur metabolism pathway related genes-namely, sulfite oxidase $(\mathrm{SO})$, sulfite reductase, and adenosine $5^{\prime}$-phosphosulfate kinase-were upregulated. It led us to examine a plausible relationship between sulfurenhanced resistance (SED) and HCRSV infection. We broadened an established method to include different concentrations of sulfur $(0 S, 1 S, 2 S$, and 3S) to correlate them to symptom development of HCRSV-infected plants. We treated plants with glutathione and its inhibitor to verify the SED effect. Disease resistance was induced through elevated glutathione contents during HCRSV infection. The upregulation of SO was related to suppression of symptom development induced by sulfur treatment. In this study, we established that HCRSV-CP interacts with SO which, in turn, triggers SED and leads to enhanced plant resistance. Thus, we have discovered a new function of SO in the SED pathway. This is the first report to demonstrate that the interaction of a viral protein and host protein trigger SED in plants. It will be interesting if such interaction applies generally to other host-pathogen interactions that will lead to enhanced pathogen defense.
\end{abstract}

Hibiscus is a common ornamental plant in Singapore and is widely distributed in the world (Brunt and Spence 2000; Huang et al. 2000; Li and Chang 2002; Tang et al. 2008; Waterworth et al. 1976). Hibiscus chlorotic ringspot virus (HCRSV) was first reported in the United States (Waterworth et al. 1976). The symptoms on HCRSV-infected plants range from a generalized mottle to chlorotic ringspots and vein-banding patterns. Many ornamental hibiscus hybrids show severe stunting and flower distortion. In the laboratory, we use kenaf (Hibisicus cannabinus L.) as a host to study HCRSV. Our earlier work indicated that HCRSV coat protein (CP) is involved in pathogenicity and is a gene-silencing suppressor (Meng et al. 2006). In addition, the $\mathrm{P}$ and $\mathrm{S}$ domains of the $\mathrm{CP}$ interact with host protein sulfite oxidase ( $\mathrm{SO}$ ), and this interaction is associated with an increased aggregation of peroxisomes in HCRSVinfected leaves (Zhang and Wong 2009).

Sulfur is an essential nutrient for plant growth, similar to nitrogen, phosphorus, and potassium (Amtmann and Armengaud 2009). It is also one of the macronutrients for plants and plays critical roles in catalytic and electrochemical functions of biomolecules in the cell (Foyer and Noctor 2009; Hesse et al.

Corresponding author: S.-M. Wong; E-mail: dbswsm@nus.edu.sg
2004; Jez et al. 2004; Rausch and Wachter 2005). Inorganic sulfur is taken up by plants from the environment, which assimilate the sulfur as sulfate $\left(\mathrm{SO}_{4}{ }^{2-}\right)$ via transport proteins (Kataoka et al. 2004; Rouached et al. 2005; Smith et al. 1995; Takahashi 2010). Subsequently, sulfate is reduced to sulfide $\left(S^{2-}\right)$ in the plastids (Rausch and Wachter 2005; Renosto et al. 1993). In the mitochondria, plastids, and cytosol, sulfide is used to form the essential amino acid cysteine (Kumaran et al. 2009; Saito 2004; Wirtz and Hell 2007), which is incorporated into sulfurcontaining defense compounds (SDC) such as glutathione (GSH), glucosinolates, and phytoalexins (Kopriva 2006; Noctor et al. 2002; Wachter et al. 2005; Zechmann et al. 2008). It is also a donor of reduced sulfur for other SDC, such as thiols, various coenzymes, and secondary metabolites. These SDC will protect plants from oxidative and environmental stresses (Bashandy et al. 2010; Foyer and Noctor 2009; Frottin et al. 2009; Koprivova et al. 2010; Marty et al. 2009; Yi et al. 2010). Thus, accumulated evidence indicated that the sulfur metabolism pathway was implicated in biotic stress resistance mechanisms, referring to sulfur-induced resistance (Bloem et al. 2005). However, because agronomic conditions are multifactorial, it is possible that sulfur-induced resistance is influenced by a number of different stresses and a combination of molecular pathways. To better understand the sulfur-induced resistance mechanism, hypothesis testing is carried out under controlled conditions by involving only the plant and a single pathogen. This concept of sulfur metabolism is termed sulfur-enhanced defense (SED), and activation of cysteine and GSH metabolism is related to SED during a compatible plant-virus interaction (Holler et al. 2010).

When plants are deprived of sulfur, they activate mechanisms to increase the uptake of sulfur from soil (Watanabe et al. 2010). However, if the plants are unable to accumulate enough sulfate, the assimilation activity in the sulfur metabolism pathway will be reduced due to decreased sulfate uptake (Hirai and Saito 2004; Hirai et al. 2003; Takahashi et al. 1997, 2000).

There are several genes related to sulfur metabolism. Among them, adenosine $5^{\prime}$-phosphosulfate $(A P S)$ kinase $(A P K)$ is used to synthesize glucosinalates (Mugford et al. 2009), sulfite reductase (SIR) reduces sulfide to sulfite (Bork et al. 1998, Yonekura-Sakakibara et al. 1998), adenosine 5'-phosphosulfate reductase $(A P R)$ reduces $A P S$ to sulfite (Kopriva et al. 2009), and $\gamma$-glutamylcysteine synthetase (GSH1, EC 6.3.2.2) forms $\gamma$-glutamylcysteine (Jez et al. 2004); these enzymes are involved in GSH synthesis. Glutathione is a key regulator of the cellular redox status. It protects plants against oxidative stress, heavy metals, herbicides, and xenobiotics and, thus, is a crucial player in the defense system of plants under abiotic and biotic 
stress (Foyer and Noctor 2009). As a redox buffer, GSH is a key molecule in the protection against reactive oxygen species (ROS), which accumulate when a plant is under stress (Rausch and Wachter 2005). ROS production is one of the most fundamental plant responses against pathogen attack, which leads to tissue necrosis and restriction of pathogen spread and activation of other host defense responses. In order for ROS to perform its dual function efficiently, cellular levels of ROS must be tightly regulated. Glutathione is one of the oxidant scavengers of the cell, lowering the overall concentration of ROS before it reaches levels which are detrimental to the plant (Foyer and Noctor 2009).

More importantly, enhanced GSH metabolism has been shown to be correlated with SED using Tobacco mosaic virus (TMV)-infected Nicotiana tabacum plants and APR and GSHI genes, which are involved in GSH biosynthesis. These genes were significantly upregulated in response to TMV infection in plants provided with sufficient sulfur, indicating that GSH metabolism is directly correlated to SED (Holler et al. 2010).

In this study, we are the first to investigate the upregulation of SIR, APK, and SO gene transcript levels in HCRSV-infected and HCRSV-CP-agroinfiltrated kenaf leaves and to examine whether there is a relationship between SED and HCRSV infection. We adopted an established method (Holler et al. 2010; Kiraly et al. 2011) to verify whether SED is triggered upon HCRSV infection, including gene transcript levels of $A P R$ and $G S H 1$, the amount of cysteine and GSH, symptom development, and HCRSV-CP accumulation. We also broadened the method by using different concentrations of sulfur (0S, $1 \mathrm{~S}, 2 \mathrm{~S}$, and $3 \mathrm{~S}$ ) to correlate them to symptom development of HCRSV-infected plants. In addition, we treated plants with GSH and its inhibitor, L-buthionine-(S,R)-sulfoximine (BSO), to verify the SED effect. To gain a deeper mechanistic insight into the SED, we focused on SO with sulfur treatments because we previously showed that HCRSV-CP interacts with SO and upregulates SO gene transcripts (Zhang and Wong 2009). Furthermore, SO has been reported to confer resistance in plants to high levels of sulfur dioxide, via coping with sulfite overflow (Brychkova et al. 2007). However, the function of SO to sulfur flux in the cells is not clear (Takahashi et al. 2011). The objective of this research was to establish that HCRSV-CP interacts with SO which, in turn, will trigger SED and lead to enhanced plant resistance. This is the first attempt to demonstrate the interaction of a viral protein and a host protein to trigger SED.

\section{RESULTS}

\section{Analysis of $S I R, A P K, S O$, and}

HCRSV-CP gene transcript levels after HCRSV infection.

In our previous study, we reported that HCRSV upregulates plant SO transcript and increases sulfate levels in kenaf (Zhang and Wong 2009). In addition, SO is involved in the sulfur metabolism pathway. We aimed to test whether the expression level of other genes related to sulfur pathway are altered after HCRSV infection. Three main enzymes (SIR, APK, and SO) that are involved in the sulfur metabolism pathway were investigated in HCRSV-infected kenaf leaves. The leaves collected were fully developed, with severe systemic mosaic and necrosis. The reason for choosing these enzymes is that they are the main downstream factors in the sulfur metabolism. To test the transcript profiles of the sulfur-related genes, a time course experiment at $3,7,10$, and 14 days postinoculation (dpi) was performed. Compared with the different time points, these gene transcripts were increased slightly from 3 to $7 \mathrm{dpi}$ and peaked at $10 \mathrm{dpi}$; thus, time point $10 \mathrm{dpi}$ was selected to show the relative gene transcript expression levels. The results showed that $S I R$ and $A P K$ gene transcript levels were upregulated twoand sixfold, respectively. The $S O$ transcript level, however, was significantly upregulated, approximately 10 -fold. The HCRSV$\mathrm{CP}$ gene transcript level was elevated to sixfold (Fig. 1). Altogether, the $S I R, A P K$, and $S O$ gene transcripts were upregulated after HCRSV infection and the significant upregulation time point was at $10 \mathrm{dpi}$. The reason could be that HCRSV-infected kenaf plants contained relatively higher amount of viruses and exhibited more severe symptoms at that time point. With higher HCRSV-CP expression (sixfold) (Fig. 1), the interaction between HCRSV-CP and SO was intensified, which resulted in higher gene transcript levels in the SED.

\section{Analysis of $S I R, A P K, S O$, and \\ HCRSV-CP gene transcript levels \\ after agroinfiltration with HCRSV-CP gene.}

Although the sulfur pathway-related genes SIR, APK, and SO were upregulated after HCRSV infection and HCRSV-CP interacts with $\mathrm{SO}$, it is uncertain whether the changes of the sulfur genes transcript levels were caused by HCRSV-CP. To test whether HCRSV-CP interacting with SO results in upregulation of related genes in the sulfur metabolism pathway, agroinfiltration with HCRSV-CP green fluorescent protein (GFP) gene experiments were performed. To investigate HCRSV-CP gene expression and fusion protein translation, confocal microscopy and Western blot with anti-GFP antibody were used. Strong GFP signals were detected from both empty-vector pGreen-GFP and pGreen-CP-GFP. The pGreen-CP-GFP was not detected in the nucleus, indicating that HCRSV-CP does not enter the nucleus. In addition to the direct observation with confocal microscopy (Fig. 2A), the CP-GFP fusion protein (68 $\mathrm{kDa}$ ) could also be detected using Western blot analysis (Fig. 2B). Using the total RNA extracted from kenaf leaves agroinfiltrated with HCRSV-CP gene, quantitative real-time reversetranscriptase polymerase chain reaction (qRT-PCR) was carried out. Results showed that $S I R, A P K$, and $S O$ were upregulated. After the HCRSV-CP gene was artificially infiltrated into the kenaf leaves, a significantly increase in transcript level (approxi-

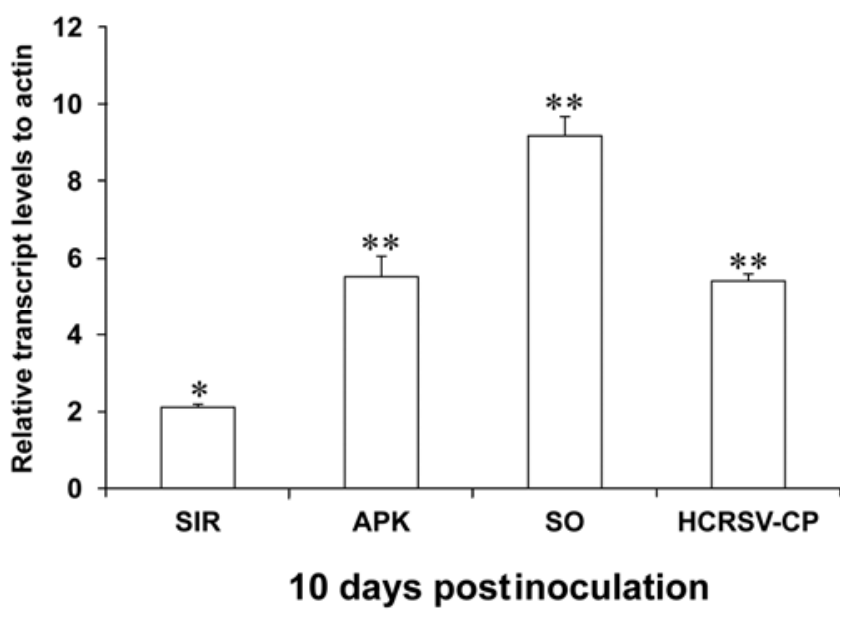

Fig. 1. Expression of sulfite reductase $(S I R)$, adenosine $5^{\prime}$-phosphosulfate kinase $(A P K)$, sulfite oxidase (SO), and Hibiscus chlorotic ringspot virus coat protein (HCRSV-CP) gene transcripts in kenaf (Hibiscus cannabinus L.) leaves 10 days postinoculation as determined by quantitative reversetranscriptase polymerase chain reaction. Relative gene transcription data (actin as internal control) was analyzed using the $2^{-\Delta \Delta C T}$ method. The value of mock control was subtracted from HCRSV samples and was not shown. Means of three independent biological repeats were shown with standard deviations. Significant differences between mock-inoculated and HCRSV-infected leaves were calculated using the one-sample $t$ test. Asterisks (* and **) indicate significance at 0.05 and 0.01 levels of confidence, respectively. 
mately 230 -fold) was observed. The $A P K$ gene showed a relatively higher expression level (30-fold) compared with the other two genes, SIR (fourfold) and SO (eightfold) (Fig. 2C). In order to further investigate the ability of HCRSV-CP to upregulate sulfur-pathway-related genes expression, a CP transient expression titration experiment was carried out. Different concentrations of Agrobacterium (optical density at $600 \mathrm{~nm}$ $\left[\mathrm{OD}_{600}\right]=0.5,1.0,1.5$, and 2.0$)$ containing increasing amount of HCRSV-CP gene were infiltrated. However, even though different amounts of Agrobacterium were used for infiltration, no differences were observed for the HCRSV-CP gene transcript expression and related sulfur genes expression.

The upregulation of SED-related gene transcripts in HCRSVinfected and HCRSV-CP-infiltrated leaves was different (Figs. 1 and 2). One possibility is that these data were obtained under two different experimental conditions. Kenaf plants infected with HCRSV undergo a natural progression of infection, whereas HCRSV-CP infiltration was an artificial system for gene expression. Therefore, overexpression of HCRSV-CP may lead to some irregularities in SED-related gene transcript levels. Another reason is that, in addition to HCRSV-CP, more genes may be involved in the regulation of SO, causing upregulation of sulfur-pathway-related genes. Regardless, all of the three SED-related genes were upregulated in both cases. This is the first demonstration that upregulation of SO, APK, and SIR is correlated to a virus CP. It is consistent with the results obtained from HCRSV-infected plants. These results led us to proceed to verify whether SED was triggered by HCRSV infection.

\section{Verification of SED to HCRSV infection.}

After observing the correlation of HCRSV infection and SED-related gene expression, we aimed to determine whether the SED pathway was involved in the HCRSV infection process. To investigate the effects of SED upon HCRSV infection, experiments were carried out following a similar protocol (Holler et al. 2010; Kiraly et al. 2011), with slight modifications. Mixing different sulfate sources provided magnesium and sodium, which are nutrients essential for maintaining normal plant growth. In this study, 1-week-old kenaf seedlings were supplemented with our different concentrations of sulfur $\left(0 \mathrm{~S}, 1 \mathrm{~S}, 2 \mathrm{~S}\right.$, and $3 \mathrm{~S}$, representing $0 \mathrm{mM} \mathrm{MgSO}_{4}+0 \mathrm{mM}$ $\mathrm{Na}_{2} \mathrm{SO}_{4}, 0.25 \mathrm{mM} \mathrm{MgSO} 4+0.63 \mathrm{mM} \mathrm{Na} \mathrm{SO}_{4}, 0.50 \mathrm{mM}$ $\mathrm{MgSO}_{4}+1.25 \mathrm{mM} \mathrm{Na}_{2} \mathrm{SO}_{4}$, and $1 \mathrm{mM} \mathrm{MgSO}_{4}+2.50 \mathrm{mM}$ $\mathrm{Na}_{2} \mathrm{SO}_{4}$, respectively). The seedlings treated with four different concentrations of sulfur were investigated at 7, 14, and 21 dpi (inoculation with HCRSV). Plants were examined at 14 dpi with HCRSV. The reason for not choosing 7 and $21 \mathrm{dpi}$ is because the leaf symptoms at $7 \mathrm{dpi}$ were not as severe as those at $14 \mathrm{dpi}$. The normal plant development was severely affected in $0 \mathrm{~S}$ plants by $21 \mathrm{dpi}$. Lower concentrations of sulfur provided to kenaf plants cultivated in sand retarded plant development. The upper leaves of $0 \mathrm{~S}$ plants showed severe chlorosis and stunting. Plants supplemented with sulfate at $1 \mathrm{~S}, 2 \mathrm{~S}$, and $3 \mathrm{~S}$ showed corresponding increases in the intensity of green leaves, and leaves from $3 \mathrm{~S}$ plants showed a lavish green and healthy appearance (Fig. 3A).

Comparing the mock- and HCRSV-infected kenaf, chlorotic and necrotic spots were only observed in HCRSV-infected kenaf plant leaves. In HCRSV-infected plants that were not supplemented with sulfur (OS), severe vein clearing and higher density of chlorotic spots were observed on the leaves. For plants supplemented with $1 \mathrm{~S}$, reduction of necrotic spots was observed. For plants supplemented with $2 \mathrm{~S}$ and $3 \mathrm{~S}$, the leaves displayed fewer disease symptoms and no necrotic spots were observed.

In addition to the symptoms observed, more molecular evidence was provided to verify that sulfur plays an essential role during HCRSV infection. It was reported that $A P R$ and GSHI were early response genes which participate in the sulfur metabolism pathway (Holler et al. 2010). Therefore, verification of $A P R$ and $G S H 1$ gene transcript levels at the early infection of HCRSV was performed. Leaves were collected at 3, 6, 12, and $24 \mathrm{~h}$ postinoculation (hpi). For all the test time points, the transcript level of $A P R$ increased in plants supplemented with higher concentrations of sulfur compared with plants without sulfur supplement (OS). Transcript level of $A P R$ increased over time and reached a peak at 12 hpi (Fig. 3B). Similarly, the GSH1 transcript level showed an upward trend with increasing concentrations of sulfur and reached its peak between 6 and 12

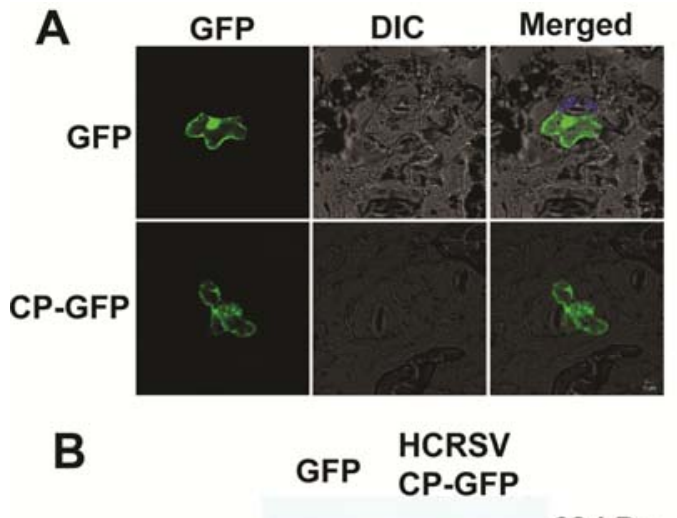

$68 \mathrm{kDa}$

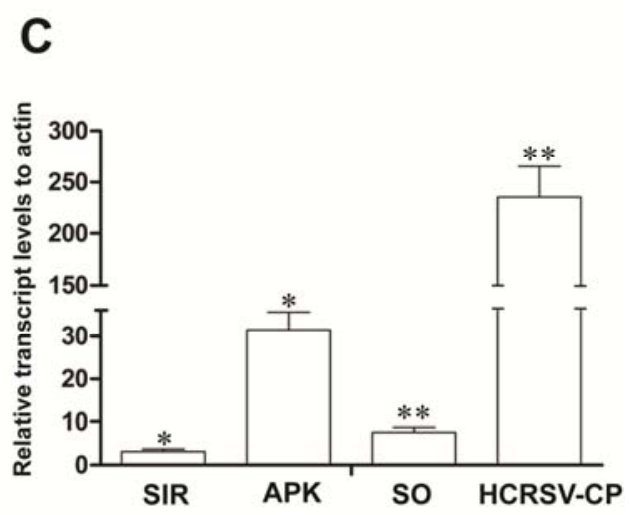

$28 \mathrm{kDa}$

Fig. 2. Gene transcript levels of sulfite reductase (SIR), adenosine $5^{\prime}$-phosphosulfate kinase (APK), sulfite oxidase (SO), and Hibiscus chlorotic ringspot virus coat protein (HCRSV-CP) after CP gene was agro-infiltrated into kenaf leaves (Hibiscus cannabinus L.), as determined by quantitative reverse-transcriptase polymerase chain reaction. A, HCRSV-CP green fluorescent protein (GFP) fusion protein expression as shown by confocal microcopy. B, Western blot analysis using GFP antibody. C, Expression of SIR, APK, SO, and HCRSV-CP gene transcripts. Relative gene transcription data was analyzed using the $2^{-\triangle A C T}$ method. Means of three independent biological repeats were shown with standard deviations. Significant differences between control infiltrated and HCRSV$\mathrm{CP}$ infiltrated leaves were calculated using the one-sample $t$ test. Asterisks ( $*$ and $* *$ ) indicate significance at 0.05 and 0.01 levels of confidence, respectively. 
hpi (Fig. 3B). Because there was insufficient sulfur provided, OS plants showed the least increase in APR and GSH1 transcript levels.

HCRSV infection and HCRSV-CP infiltration experiments indicated that the SED-related genes SIR, $A P K$, and $S O$ were upregulated (Figs. 1 and 2). In addition, cysteine, as an essential component of GSH synthesis, is the downstream product of the sulfur pathway. The GSH could be artificially increased by cysteine supplement (Gullner et al. 1999; Harms et al. 2000; Zechmann et al. 2007). Furthermore, the increased level of cysteine and the subsequent amount of GSH was correlated with a higher level of sulfate (Bloem et al. 2004; Dekok et al. 1981; Schnug et al. 1995). However, the amounts of cysteine and GSH in young leaves decreased significantly (Blake-Kalff
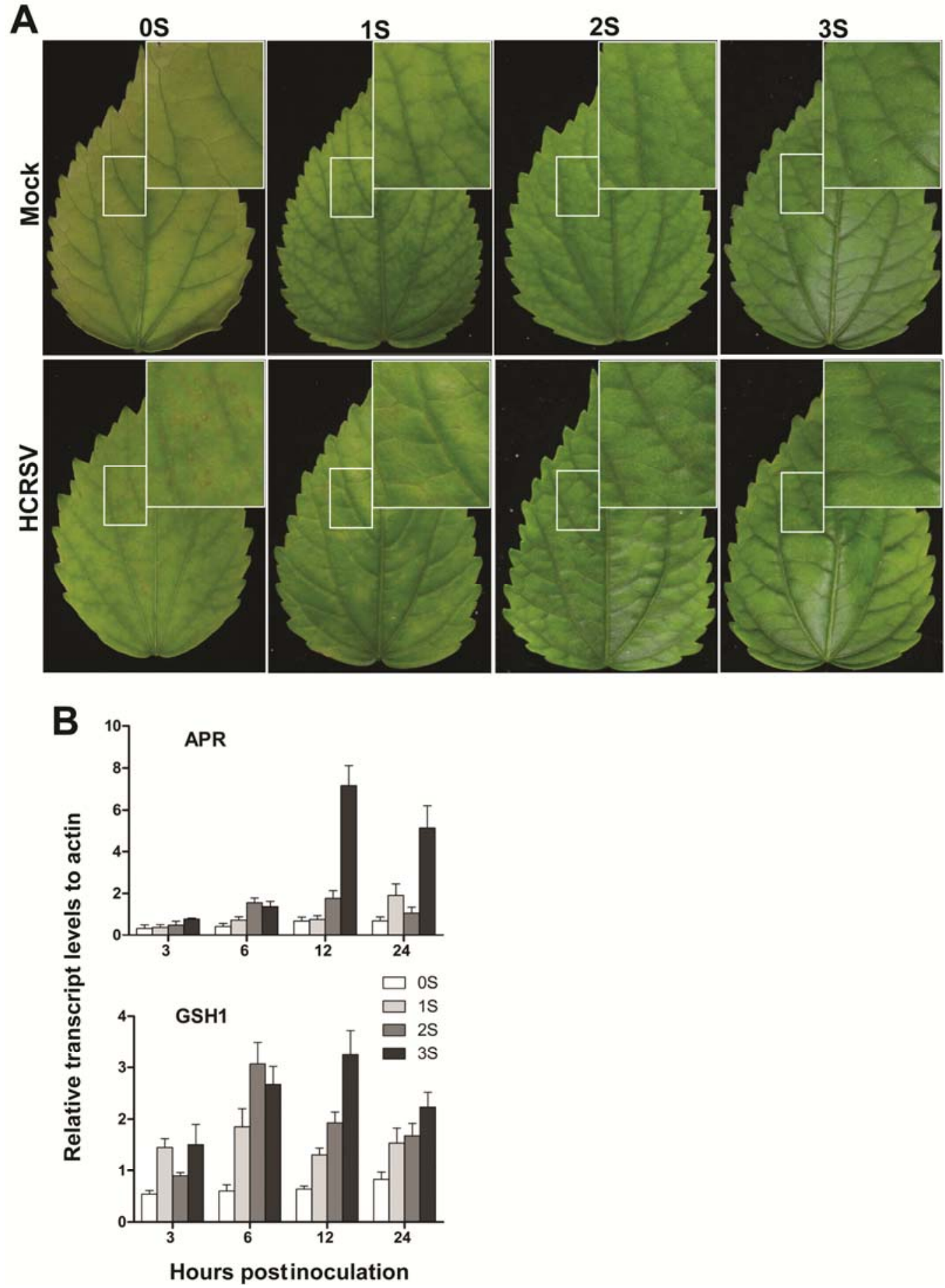

Fig. 3. Symptoms and gene transcripts levels of adenosine 5 '-phosphosulfate reductase (APR) and $\gamma$-glutamylcysteine synthetase (GSHI) of kenaf subjected to different concentrations of sulfate solution: 0S, 1S, 2 S and 3S. A, Symptoms of kenaf mock and Hibiscus chlorotic ringspot virus (HCRSV)-infected leaves supplemented with $0 \mathrm{~S}, 1 \mathrm{~S}, 2 \mathrm{~S}$, and $3 \mathrm{~S}$ sulfate solutions at 14 days postinoculation. Prominent chlorotic spots were observed on HCRSV-infected leaves at 0 S. Solutions $1 \mathrm{~S}, 2 \mathrm{~S}$, and $3 \mathrm{~S}-0.25 \mathrm{mM} \mathrm{MgSO}+0.63 \mathrm{mM} \mathrm{Na} \mathrm{SO}_{4}, 0.50 \mathrm{mM} \mathrm{MgSO}+1.25 \mathrm{mM} \mathrm{Na}_{2} \mathrm{SO}_{4}$, and $1.00 \mathrm{mM} \mathrm{MgSO}+2.50 \mathrm{mM}$ $\mathrm{Na}_{2} \mathrm{SO}_{4}$, respectively, all with extra amount of sulfur-were provided to kenaf plants grown in sand. $\mathbf{B}, A P R$ and GSH1 genes transcript levels were analyzed in the kenaf leaves at 3,6,12, and 24 hours postinoculation using quantitative reverse-transcriptase polymerase chain reaction. Means of three independent biological repeats with standard deviations were shown. Significant differences between mock-inoculated and HCRSV-infected leaves were calculated using the $t$ test $(P<0.01)$. Two-way analysis of variance of $A P R$ and $G S H 1$ gene transcript levels showed that there were significant differences between different sulfur concentrations $(P<0.05)$ but not at different time points. 
et al. 2000; Nikiforova et al. 2006; Parmar et al. 2007). In this study, the amounts of cysteine and GSH were investigated using immuno-gold electron microscopy (IEM). Mock and 3Ssupplemented kenaf plants were selected. From the IEM, the presence of cysteine or GSH inside plant organelles was observed as electron-dense dots (gold particles) on the electron micrographs. More dots indicated larger amounts of cysteine or GSH. The amount of immuno-gold particles was quantified in chloroplasts and peroxisomes. More gold particles were observed in both organelles of 3S-supplemented kenaf plants at 14 dpi (Fig. 4). Comparing 3S-supplemented and 0S plants after HCRSV infection for cysteine content, the number of gold particles per unit area (square micrometers) was approximately eightfold higher in chloroplasts and fourfold higher in peroxisomes (Fig. 4A). Similarly, for GSH content, it was approximately fivefold higher in chloroplasts and threefold higher in peroxisomes (Fig. 4B). Cysteine is an upstream molecule which leads to the production of GSH in the sulfur metabolism pathway which, in turn, is involved in plant defense (Foyer and Noctor 2009). Higher amounts of cysteine and GSH in 3S-supplemented plants further indicated that $3 \mathrm{~S}$ plants were more resistant to HCRSV infection, because both symptoms and the amount of virus were greatly reduced.

After demonstrating that $3 \mathrm{~S}$-supplemented plants contained more GSH, which is involved in SED, the HCRSV-CP gene transcript level was quantified at 7, 14, and 21 dpi to confirm that 3S-supplemented kenaf plants were more resistant, using qRT-PCR and Western blot analysis. At 14 dpi, the HCRSV$\mathrm{CP}$ transcript level in the $\mathrm{OS}$ plants was significantly higher than that of the $3 \mathrm{~S}$ plants, indicating that the $0 \mathrm{~S}$ plants were least resistant to virus infection (Fig. 5A).

Although HCRSV-CP may interact with SIR or APK to trigger SED, we focused on SO in the $0 \mathrm{~S}$ and $3 \mathrm{~S}$ treatments because, previously, we had shown that there is a strong interaction between HCRSV-CP and SO (Zhang and Wong 2009). As expected, $S O$ also showed higher expression in the $3 \mathrm{~S}$ plants (Fig. $5 \mathrm{~A})$. Because the $3 \mathrm{~S}$ plants are supplemented with higher amounts of sulfate, it would be reduced to sulfite by APR. However, the presence of a large amount of sulfite in plants is toxic. Thus, SO serves as a "safety valve" to detoxify excess amounts of sulfite and protect the cells from sulfitolysis (Hansch et al. 2007). The HCRSV-CP expression levels in the $3 \mathrm{~S}$ plants were lower than the 0 S plants at 7, 14, and 21 dpi (Fig. 5B).

\section{Comparison of symptoms and HCRSV accumulation in infected kenaf plants pretreated with $\mathrm{H}_{2} \mathrm{O}$, BSO, or GSH.}

Because GSH plays a key role in enhancing plant defense during virus infection (Holler et al. 2010; Kiraly et al. 2011) then, logically, direct provision of GSH to plants will increase resistance and inhibiting GSH synthesis will reduce plant resistance. Three groups of plants, first treated with $\mathrm{H}_{2} \mathrm{O}, \mathrm{BSO}$, or GSH, followed by HCRSV inoculation, were investigated for symptom expression and HCRSV accumulation. The time point at $11 \mathrm{dpi}$ was chosen because the virus titer reached its highest level. All mock-inoculated plants exhibited no chlorotic spots, whereas severe chlorotic spots were clearly manifested on HCRSV-inoculated plants (Fig. 6A). Comparing the
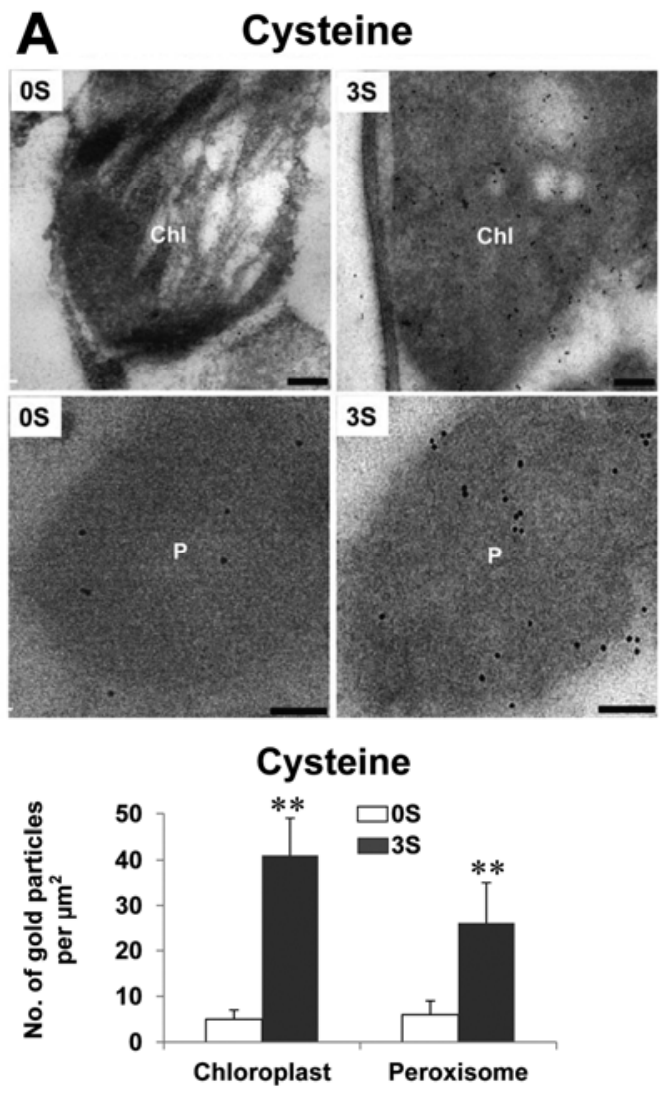

B
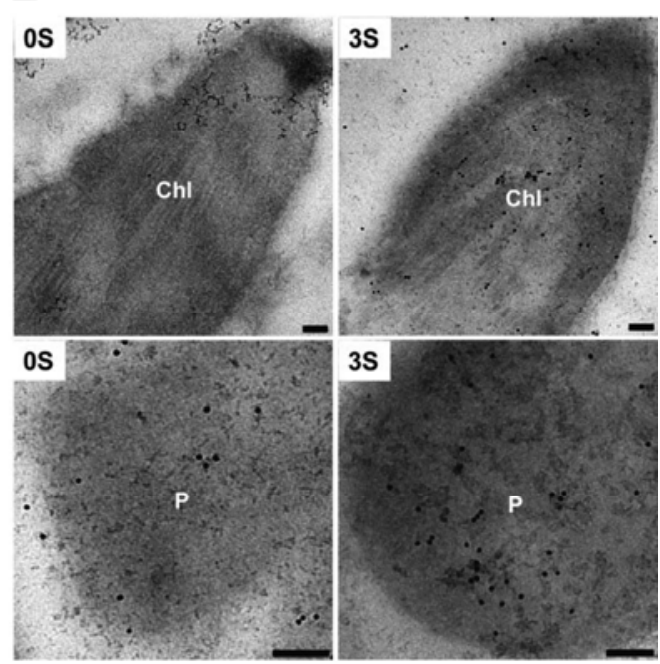

Glutathione

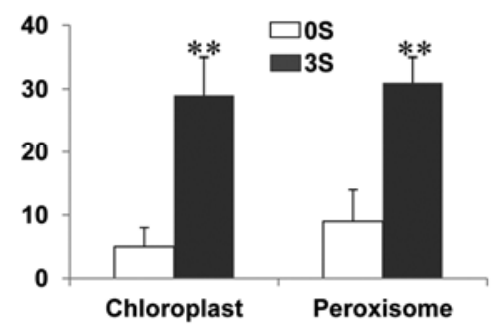

Fig. 4. Quantification of A, cysteine and B, glutathione (GSH) in 0S- and 3S-supplemented kenaf plants 14 days after Hibiscus chlorotic ringspot virus infection using immuno-electron microscopy. Gold particles per unit area (square micrometers) were counted in organelles of chloroplasts and peroxisomes, which were involved in cysteine and GSH biosyntheses. Thin sections were first incubated with cysteine or GSH antiserum separately and, subsequently, with goat anti-rabbit secondary antibody conjugated to 10-nm gold particles. Number of immuno-gold particles in chloroplasts and peroxisomes was counted. Data include means with standard errors. Significant differences were calculated using the Kruskal-Wallis test. Asterisks (**) indicate significance at the 0.01 level of confidence. Chl, chloroplast; $\mathrm{P}$, peroxisome; bar $=100 \mathrm{~nm}$. 
symptoms of plants receiving the three different types of treatments, HCRSV-infected plants treated with $0.1 \mathrm{mM}$ BSO displayed the highest density of chlorotic spots, followed by plants that were treated with water (exhibiting typical symptoms of HCRSV infection). The plants treated with $1 \mathrm{mM}$ GSH solution manifested the least severe symptoms, because only a few chlorotic spots were observed on the leaves (Fig. 6A).

In addition to the direct symptom comparison after HCRSV infection, HCRSV-CP was also compared in its relative amount using Western blot analysis. Among $\mathrm{H}_{2} \mathrm{O}-$, BSO-, and GSH-treated plants, the intensity of the HCRSV-CP band (38 $\mathrm{kDa}$ ) was most prominent in BSO-treated plants, followed by that of $\mathrm{H}_{2} \mathrm{O}$-treated and $\mathrm{GSH}$-treated plants (Fig. 6B). The HCRSV-CP gene expression was further confirmed using enzyme-linked immunosorbent assay (ELISA). The amount of HCRSV-CP present in kenaf leaves treated with $1 \mathrm{mM} \mathrm{GSH}$ was significantly lower than that of both $\mathrm{H}_{2} \mathrm{O}$-treated plants and $0.1 \mathrm{mM}$ BSO-treated plants. The BSO-treated kenaf contained the highest amount of HCRSV-CP in total protein extracts of the leaves compared with that of the other two treatment groups (Fig. 6C). The results indicated that GSH plays a role in the HCRSV infection process as a plant defense enhancer. In short, to demonstrate the SED effect upon HCRSV infection, we first broadened the method to include different concentrations of sulfur $(0 \mathrm{~S}, 1 \mathrm{~S}, 2 \mathrm{~S}$, and $3 \mathrm{~S})$ in order to correlate them to symptom development in HCRSV infected plants, followed by further treating the plants with BSO and GSH to verify the SED effect.

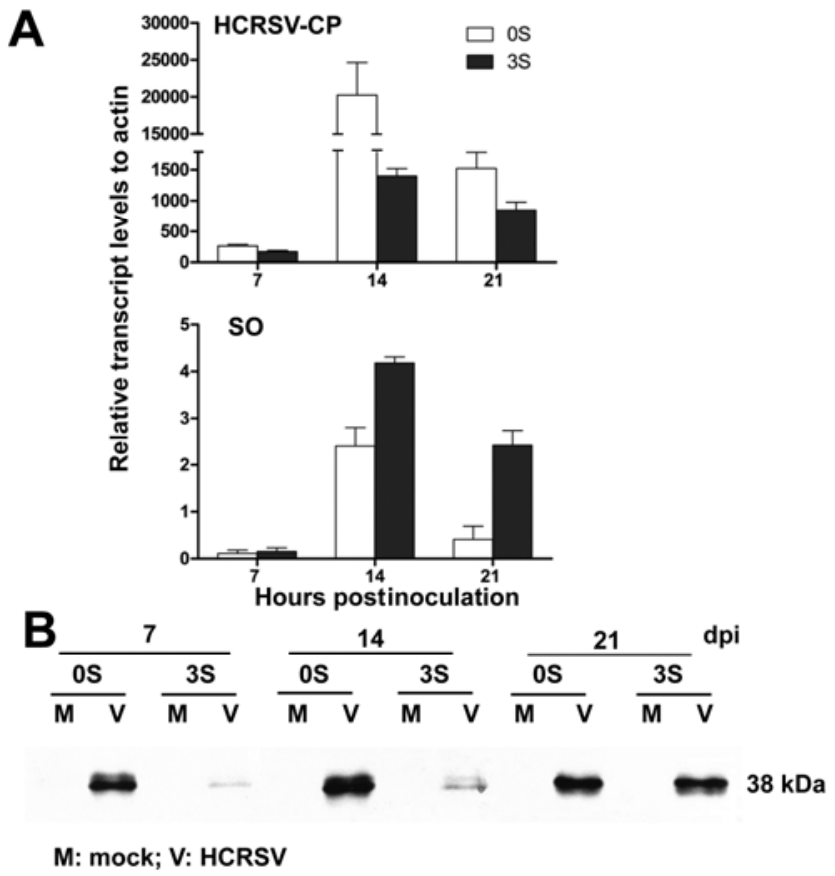

Fig. 5. Gene transcripts and Hibiscus chlorotic ringspot virus coat protein (HCRSV-CP) between OS- and 3S-supplemented kenaf (Hibiscus cannabinus L.) plants. A, HCRSV-CP and sulfite oxidase $(S O)$ gene transcripts in HCRSV-infected kenaf leaves, with or without sulfur supplement, as determined by quantitative reverse-transcriptase polymerase chain reaction. B, HCRSV-CP was detected using HCRSV-CP antiserum at 7, 14, and 21 days postinoculation in $0 \mathrm{~S}$ - and $3 \mathrm{~S}$-supplemented kenaf plants. Relative gene expression data were analyzed using $2^{-\Delta \Delta C T}$ method. Means of three independent biological repeats are shown by standard deviations. Significant differences between mock-inoculated and HCRSV-infected leaves were calculated using the $t$ test $(P<0.01)$. Paired group analysis of relative transcript levels of individual HCRSV-CP and SO over time showed that there were significant differences between the 0S- and 3S-supplemented kenaf plants, using the Tukey-Kramer method $(P<0.05)$.

\section{DISCUSSION}

Our previous research indicated the interaction of HCRSV$\mathrm{CP}$ and SO as well as the upregulation of SO occurs but the mechanism of the interaction was unknown (Zhang and Wong 2009). We decided that, because SO is involved in the sulfur metabolism pathway, we would choose two other sulfur-pathway-related genes, SIR and APK, which are involved in synthesis of the SDC glucosinalates and GSH, respectively (Fig. 7), to investigate their gene transcript levels in both HCRSV-infected and HCRSV-CP agroinfiltrated kenaf leaves. The results showed that $S I R, A P K$, and $S O$ were all upregulated. This led us to investigate whether HCRSV infection can trigger SED and whether the interaction of HCRSV-CP and SO is involved in the process of SED.

With regards to the upregulation of $S I R$ and $A P K$ genes, both genes are used to synthesize glucosinolates and GSH, which could enhance plant defense (Fig. 7). In addition, SIR, a chloroplast-localized enzyme, has been shown to be rapidly induced in an SO-dependent manner (Brychkova et al. 2007). The upregulation of SO is believed to accelerate detoxification of excess sulfite to sulfate, balancing their intracellular ratio. Therefore, SO plays a regulatory role in the sulfur metabolism pathway. Because $\mathrm{H}_{2} \mathrm{O}_{2}$ is a byproduct arising from the catalytic activity of SO, it has a ROS property which is involved in the signaling pathway for plant defense. The upregulation of $S O$ gene transcript levels may be used by kenaf plants to resist viral infection. Upregulation of three SED-related genes resulted in generation of the SDC, indicating that plant defense is induced upon interaction of a protein in the SED pathway with a virus CP such as HCRSV-CP.

To further strengthen the notion that SED was induced upon HCRSV infection, additional sulfur was provided to plants. The results showed that increasing amount of sulfate correspondingly enhanced plant resistance against HCRSV. After HCRSV infection, plants supplemented with 3S displayed delayed symptom development through upregulation of gene transcripts of $A P R$ and GSH1. APR is a key regulator of the SED and is strictly regulated by the availability of sulfur. Transcript level of $A P R$ is tightly correlated with intracellular cysteine level (Leustek et al. 2000). The APR transcript level was significantly increased within 24 hpi of HCRSV, and this upregulation was most significant for plants supplemented with 3S (Fig. 3B). Transcript level of the GSH1 was also upregulated within 24 hpi of HCRSV infection. GSH1 is the rate-limiting enzyme involved in the biosynthesis of GSH, which is also dependent on cysteine availability. Previous studies reported that both $A P R$ and $G S H 1$ were upregulated in tobacco plants within the first day of TMV infection under a $+\mathrm{S}$ condition (Holler et al. 2010), indicating that these two genes were earlyresponse genes. In this study, $A P R$ and $G S H I$ were also tested according to a time-point experiment carried out at $3,6,12$, and $24 \mathrm{~h}$, and we extended the time points to 3, 7, 10, and 14 dpi, respectively. The results showed a similar upward trend for both of the transcript levels (data not shown). Sufficient sulfur is required by kenaf to mount a successful defense against HCRSV infection. This is in agreement with a recent finding which showed that sufficient sulfate supply enhances plant defense, resulting in reduced symptoms and TMV accumulation in $N$. tabacum (Kiraly et al. 2011). Furthermore, it is reported that elevated GSH concentrations are strongly correlated with the development of tolerance during Zucchini yellow mosaic virus infection using cyto-histochemical method (Zechmann and Mueller 2008). In addition, increased amounts of cysteine and GSH lower HCRSV-CP gene transcript and protein levels in sulfur-sufficient $3 \mathrm{~S}$ plants, suggesting that sufficient sulfate enhances kenaf plant resistance to HCRSV infection. 
Another observation is that the plant leaves treated with 0S showed severe chlorosis. There is a report on downregulation in the rate of photosynthesis in the green algae Chlamydomonas reinhardtii under sulfur-deprived conditions (Wykoff et al. 1998). Similar phenomena may also occur in higher plants such as kenaf.

A new approach was used to demonstrate whether GSH enhances plant resistance (Fig. 6). GSH treatment alleviates symptom severity in HCRSV-infected kenaf. It is believed that GSH is linked to plant defense mechanisms via upregulating defense-related genes, and also through buffering the cytosol against ROS (Foyer and Noctor 2009). Our investigation showed that, by providing GSH to the plants, it has a repressive effect on symptom manifestation. Virus titer was also lower in plants treated with GSH. BSO suppresses GSH through inhibition of GSH1 to lower intracellular GSH contents. BSO-treated plants showed the most severe symptoms. Glutathione may protect plants against oxidative stress and play a key role in plant defense. Thus, GSH is believed to be involved in the SED pathway upon HCRSV infection.

In conclusion, this study showed that HCRSV-CP can interact with $\mathrm{SO}$ to trigger upregulation of genes $S I R$ and $A P K$ related to SED, increasing the amount of GSH, which is a SDC to enhance plant defense. We established that HCRSV-CP interacts with SO which, in turn, triggers SED and leads to enhanced plant resistance. This is the first report to demonstrate the interaction of a viral protein and host protein to trigger SED in a virus-host system, as well as indicating a novel function of SO. It will be interesting to see whether such interaction applies generally to other host-pathogen interactions that will lead to enhanced pathogen defense.

\section{MATERIALS AND METHODS}

Plant materials and preparation of sulfur solution.

Kenaf seed ('Everglade 41') were purchased from Mississippi State University and germinated on potting mixture (Universalerde Universal Potting Soil, Moerdijk, The Netherlands) for 7 days. Kenaf seedlings (1 week old) supplemented with four different concentrations of sulfur $(0 \mathrm{~S}, 1 \mathrm{~S}, 2 \mathrm{~S}$, and $3 \mathrm{~S}$, representing $0 \mathrm{mM} \mathrm{MgSO}{ }_{4}+0 \mathrm{mM} \mathrm{Na}_{2} \mathrm{SO}_{4}, 0.25 \mathrm{mM} \mathrm{MgSO}_{4}+$ $0.63 \mathrm{mM} \mathrm{Na}_{2} \mathrm{SO}_{4}, 0.50 \mathrm{mM} \mathrm{MgSO}{ }_{4}+1.25 \mathrm{mM} \mathrm{Na}_{2} \mathrm{SO}_{4}$, and $1.00 \mathrm{mM} \mathrm{MgSO} 4+2.50 \mathrm{mM} \mathrm{Na}_{2} \mathrm{SO}_{4}$ respectively) were transferred into sand after emergence of true leaves, and each treatment included 34 seedlings. Subsequently, kenaf seedlings were supplemented with nutrient solutions containing four different concentrations of sulfur over 21 days. In addition, the plants were irrigated with a soluble fertilizer solution of nitrogen, phosphorus, and potassium (NPK, 21-21-21), twice a week, to maintain a constant moist environment for the roots. For kenaf seedlings used for HCRSV infection and Agrobacterium infiltration experiments, the seedlings were transferred to potting mixture. All plants were grown under greenhouse conditions of $16 \mathrm{~h}$ of light and $8 \mathrm{~h}$ of darkness at $25^{\circ} \mathrm{C}$.

\section{Virus inoculation.}

The youngest fully developed leaves from HCRSV-infected kenaf exhibiting chlorotic spots $(0.1 \mathrm{~g})$ were homogenized in $0.5 \mathrm{ml}$ of virus inoculation buffer $(0.01 \mathrm{M}$ phosphate buffer, $\mathrm{pH}$ 7.0) and used for inoculation. Mock inoculation was carried out by rubbing inoculation buffer alone onto the cotyledons. Fully developed young leaves were harvested at 3, 6, 12, and 24 hpi to quantify $A P R$ and $G S H 1$ transcript levels through
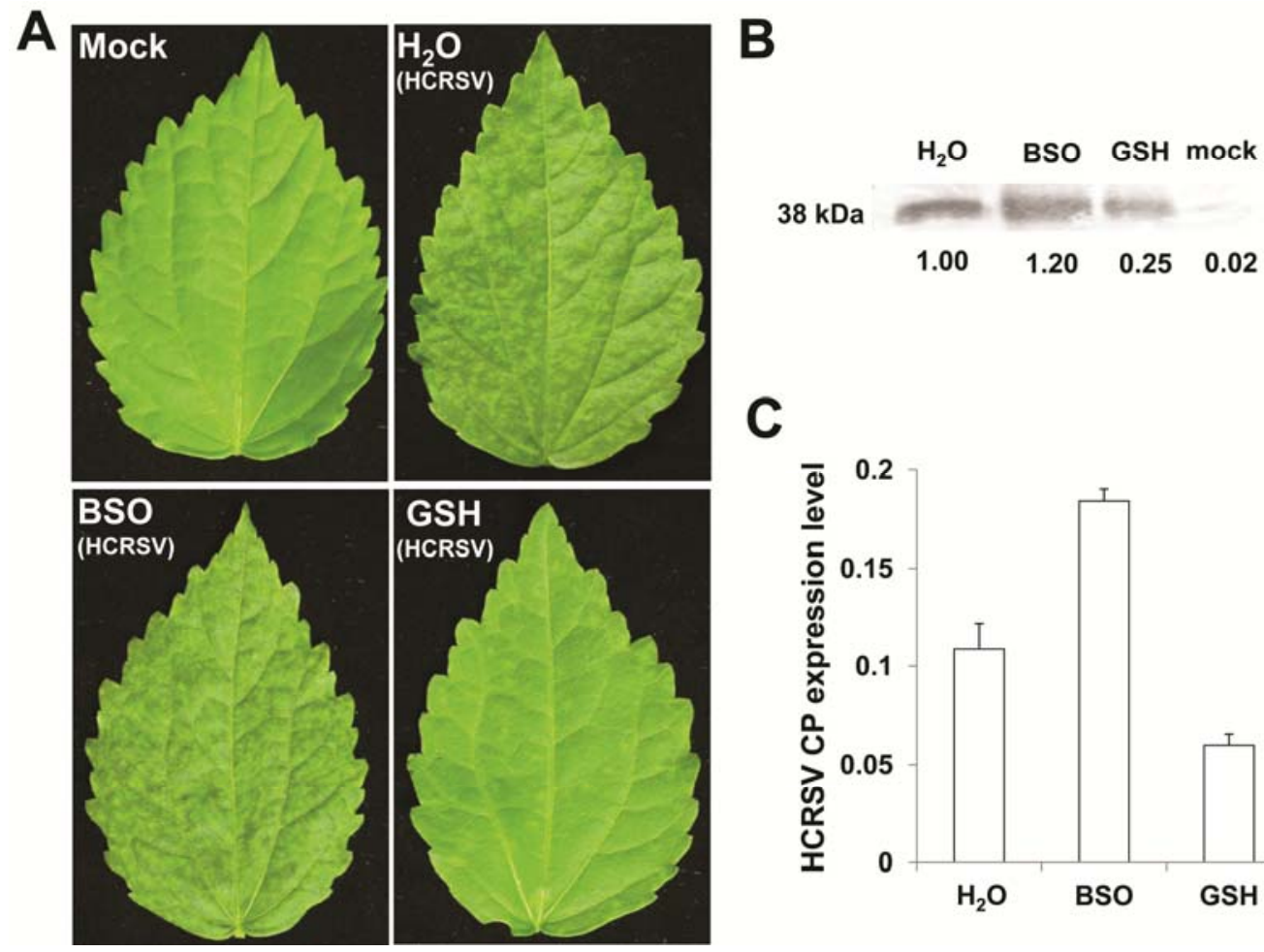

\section{C}

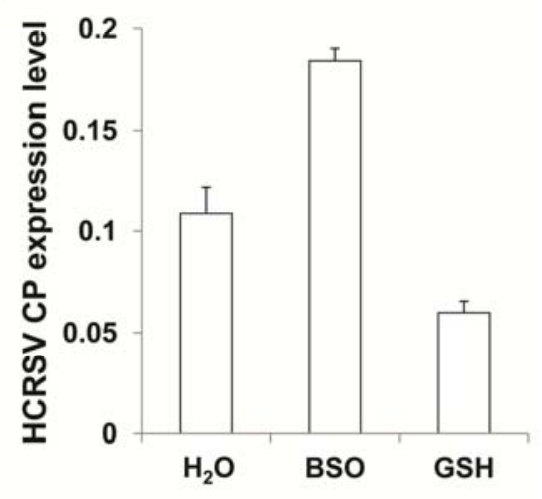

Fig. 6. Comparison of symptom expressions and Hibiscus chlorotic ringspot virus coat protein (HCRSV-CP) accumulation in HCRSV-infected kenaf leaves under $\mathrm{H}_{2} \mathrm{O}$, L-buthionine-(S,R)-sulfoximine (BSO, a glutathione [GSH] synthesis inhibitor), and GSH treatments at 11 days postinoculation. Plants were treated with $\mathrm{H}_{2} \mathrm{O}, 0.1 \mathrm{mM}$ BSO, or $1 \mathrm{mM} \mathrm{GSH}$ solution for $24 \mathrm{~h}$ prior to inoculation with HCRSV. Mock-inoculated plants were also treated with $\mathrm{H}_{2} \mathrm{O}$, BSO, or GSH. A, GSH treatment alleviates symptom development in HCRSV-infected kenaf. Because no symptoms appeared on all mock inoculated leaves, only one representative leaf from mock plants was shown. B, Western blot. The band intensity was quantified using ImageJ. C, Enzymelinked immunosorbent assay (ELISA). Total protein extracts of kenaf leaves were used to detect the expression levels of HCRSV-CP. One-way analysis of variance and paired group analysis (Tukey-Kramer method) of ELISA results showed that all groups compared were significantly different from each other $(P<0.05)$. 
qRT-PCR. This experiment was carried out thrice. Fully developed youngest leaves with severe HCRSV infection symptoms were collected for RNA extraction.

GSH treatment on HCRSV-inoculated kenaf plants.

After seed germination on soil, 1-week-old kenaf seedlings were supported with wooden sticks in 50-ml solutions of 1.0 mM GSH, 0.1 mM BSO (Sigma-Aldrich. St. Louis), or $\mathrm{H}_{2} \mathrm{O}$ for a period of $24 \mathrm{~h}$. L-GSH in its reduced form (Sigma-Aldrich) was diluted in $\mathrm{H}_{2} \mathrm{O}$ to a final concentration of $1.0 \mathrm{mM}$. BSO was diluted to $0.1 \mathrm{mM}$ in $\mathrm{H}_{2} \mathrm{O}$. BSO significantly inhibits GSH synthesis through inhibition of $\gamma$-glutamylcysteine synthetase (Campbell et al. 1991; Griffith and Meister 1979). Each treatment was carried out by completely immersing the roots in their respective solutions in separate plastic containers. BSO and GSH solutions provided for plants were replaced with fresh solutions every $6 \mathrm{~h}$. Treated seedlings were then potted into potting mixture after $24 \mathrm{~h}$. The young seedlings would be damaged if the BSO and GSH treatments exceeded $24 \mathrm{~h}$. HCRSV inoculation was performed on 2-week-old seedlings. A mock inoculation control was included for each $\mathrm{H}_{2} \mathrm{O}$ and BSO treatments. This experiment was repeated twice.

\section{Construction of plasmids and detection of HCRSV-CP-GFP in agroinfiltrated leaves.}

The HCRSV-CP gene coding region was amplified via PCR using appropriate primers: HcCP-F (5'-3') CTGAATTCCA TGCTGCAGAAGAATGACC and HcCP-R (5'-3') GCGGAT CCGTTCCTACAGGCCCAC. A pGreen-CP-GFP was constructed using a $35 \mathrm{~S}$ pGreen-GFP vector and then transferred into Agrobacterium sp. strain GV3101 using electroporation.
Agrobacteria containing the individual plasmid of pGreenGFP or pGreen-CP-GFP were grown to $\mathrm{OD}_{600}=1.0$ to 1.5 in Luria-Bertani liquid medium and harvested by centrifugation. The cell pellet was resuspended in buffer $(\mathrm{pH} 7)$ containing 10 $\mathrm{mM}$ each $\mathrm{MgCl}_{2}$ and $\mathrm{MES}$ and $100 \mu \mathrm{M}$ acetosyringone and kept at room temperature for $4 \mathrm{~h}$. Kenaf leaves were infiltrated as previously described (Zhou et al. 2006). Images were obtained using a confocal laser scanning microscope (LSM510 META confocal; Carl Zeiss, Jena, Germany). This experiment was repeated twice.

\section{RNA extraction and cDNA synthesis.}

Youngest fully developed leaves were collected at various time points postinoculation with HCRSV, after systemic infection was successfully established with discernible symptoms. For detection of sulfur-related gene transcript levels, leaves were collected at 3, 7, 10, and 14 dpi. For effects of sulfur concentration on disease defense, leaves were collected at 3,6,12, and 24 hpi. For BSO or GSH treatments and agroinfiltrated pGreen+CP-GFP genes, kenaf leaves were collected at $11 \mathrm{hpi}$ (leaves with severe virus infection symptoms) and $68 \mathrm{hpi}$, respectively. RNA was extracted using TRIzol reagent (Invitrogen, Carlsbad, CA, U.S.A.). Total RNA ( 2 to $3 \mu \mathrm{g}$ ) was used to generate cDNAs through reverse transcription, using oligo $(\mathrm{dT})_{15}$ as primer and the SuperScript III Reverse Transcriptase kit (Invitrogen).

\section{Real-time qRT-PCR.}

Expression levels of selected transcripts were analyzed via qRT-PCR after cDNA synthesis. qPCR was set up in a total volume of $5 \mu \mathrm{l}$ in a 384-well plate and carried out on the

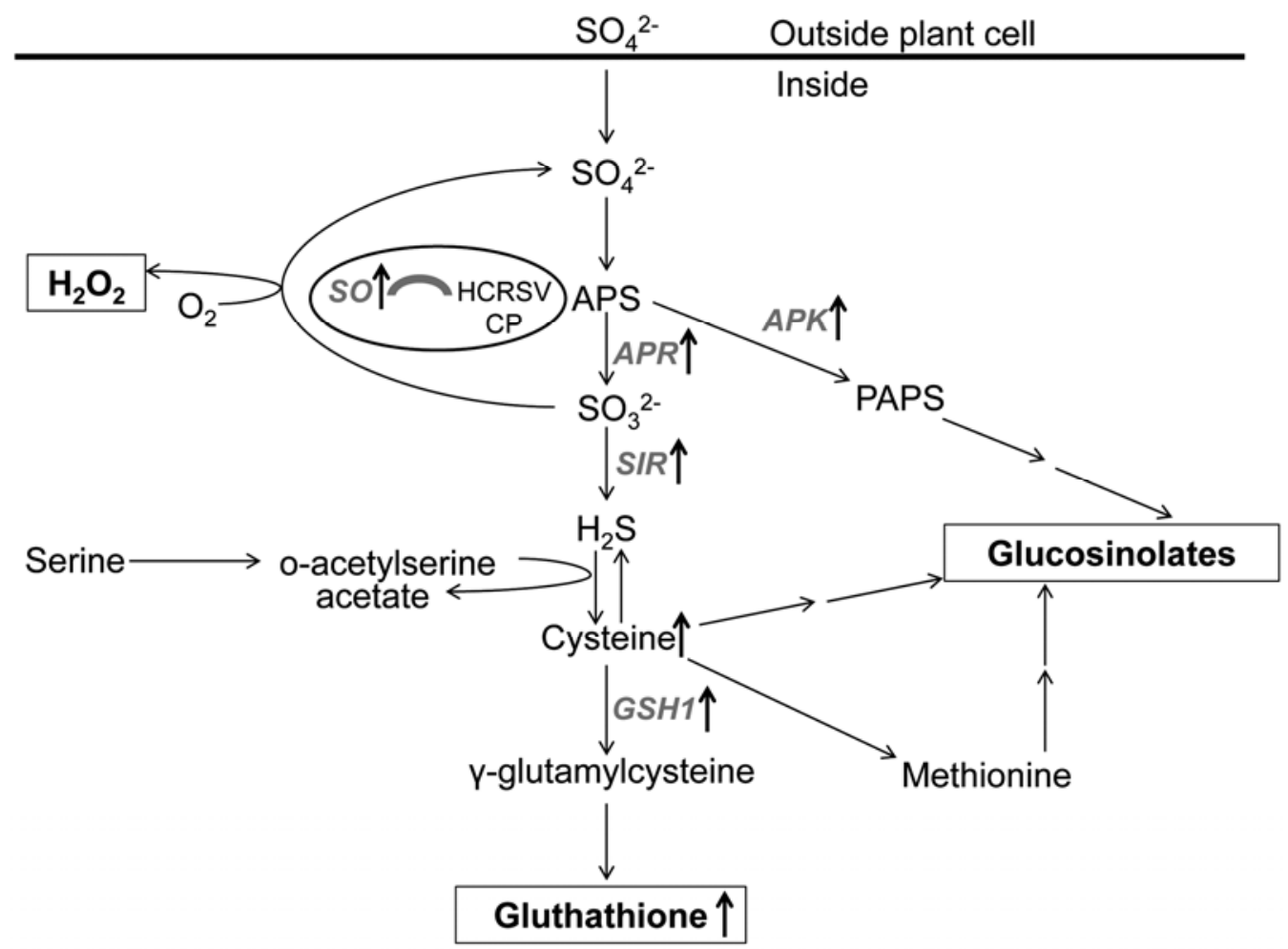

Fig. 7. Biosynthesis of sulfur-containing defense compounds (SDC, boxed). After uptake of sulfate into the plant cells, it is largely transported to the shoot. The product, APS (adenosine 5'-phosphosulfate), is reduced by APS reductase (APR). Alternatively, APS is further activated by APS kinase (APK) to form $3^{\prime}$-phosphoadenylylsulfate (PAPS), which is required for various sulfatation reactions, including the biosynthesis of glucosinolates. Sulfite is reduced by sulfite reductase (SIR) to $\mathrm{H}_{2} \mathrm{~S}$, which is incorporated into o-acetylserine via o-acetyl(thiol)lyase to form cysteine. Cysteine is incorporated into glutathione (GSH) via $\gamma$-glutamylcysteine synthetase (GSH1). Note that Hibiscus cannabinus sulfite oxidase (SO) catalyzes excess sulfite into sulfate, producing $\mathrm{H}_{2} \mathrm{O}_{2}$, which enhances plant defense system. Hibiscus chlorotic ringspot virus coat protein interacts with SO and upregulates SO, APK, and SIR (figure modified from Rausch and Wachter 2005). 
Table 1. Gene-specific primers used in quantitative reverse-transcriptase polymerase chain reaction

\begin{tabular}{|c|c|c|}
\hline Gene $^{a}$ & Primer & Primer sequence $\left(5^{\prime}-3^{\prime}\right)$ \\
\hline \multirow[t]{2}{*}{ Sulfite oxidase $(S O)$} & SO-qF247 & ATGTCAGGATGCTGCCAAAAT \\
\hline & SO-qR381 & TGCTCATGGCAGTCCTCCTAT \\
\hline \multirow[t]{2}{*}{ HCRSV coat protein $(\mathrm{CP})$} & CP-qF3486 & TGGGATGGAGGTGAAGCAGAA \\
\hline & CP-qR3610 & ACCAAGTGAGTGTGCCTGTG \\
\hline \multirow[t]{2}{*}{$5^{\prime}$-Adenylylsulfate reductase $(A P R)$} & APR-qF239 & TGAAGTGGAACCCTGTTGCC \\
\hline & APR-qR343 & TGGACACAAATCCTTGGGAATG \\
\hline \multirow[t]{2}{*}{$\gamma$-Glutamylcysteine synthetase $(G S H 1)$} & GSH1-qF359 & TGCGGCATTTGTCTGTTTCTG \\
\hline & GSH1qR463 & GCAAGTATTGGTGGCTCGTC \\
\hline \multirow[t]{2}{*}{ APS kinase $(A P K)$} & APK-qF72 & GTTGGCTTACATACCTTGATGGTG \\
\hline & APK-qR206 & TGAGTCCAGCATCAGCAAAGA \\
\hline \multirow[t]{2}{*}{ Sulfite reductase $(S I R)$} & SiR-qF537 & TTCTGTGTGACATTCGTAGTGC \\
\hline & SiR-qR654 & GCTGGACAAGCCATAGCAGT \\
\hline \multirow{2}{*}{ Hibiscus cannabinus actin } & HcAct-qF603 & ACGAGCAGGAACTGGAGACT \\
\hline & HcAct-qR734 & TGAGTGATGGCTGGAAGAGGA \\
\hline
\end{tabular}

${ }^{\mathrm{a}} \mathrm{HCRSV}=$ Hibiscus chlorotic ringspot virus and APS = adenosine 5'-phosphosulfate.

CX384 real-time PCR detection system (Bio-Rad, Hercules, CA, U.S.A.). Each reaction consisted of $1 \mu \mathrm{l}$ of cDNA template and $0.1 \mu \mathrm{l}$ each of both gene-specific forward and reverse primers $(10 \mu \mathrm{M})($ Table 1$)$, and topped up to $5 \mu \mathrm{l}$ with water. An actin gene was used as internal control for all qPCR experiments. Each test consisted of three biological sample repeats and each sample contained three replicates.

\section{Extraction of total proteins.}

Kenaf leaves were homogenized in the ratio of $0.1 \mathrm{~g}$ of leaf to $0.2 \mathrm{ml}$ of protein extraction buffer $(220 \mathrm{mM}$ Tris- $\mathrm{HCl}[\mathrm{pH}$ 7.4], $250 \mathrm{mM}$ sucrose, $50 \mathrm{mM} \mathrm{KCl}, 1 \mathrm{mM} \mathrm{MgCl}_{2}, 2 \mathrm{mM}$ phenylmethylsulfonyl fluoride, $10 \mathrm{mM} \beta$-mercaptoethanol, and $1 \times$ complete EDTA-free protease inhibitor) (Sigma-Aldrich). The homogenate was centrifuged for $10 \mathrm{~min}$ at $4^{\circ} \mathrm{C}$ and $16.1 \times 10^{3}$ $g$. The supernatant was separated and stored at $-20^{\circ} \mathrm{C}$.

\section{Western blot and ELISA.}

For Western blot, proteins were separated by denaturing $12 \%$ sodium dodecyl sulfate polyacrylamide gel electrophoresis gels and blotted onto nitrocellulose membranes (Bio-Rad). Blotted proteins were probed with anti-HCRSV or anti-GFP antibody, followed by alkaline phosphatase-conjugated protein A or anti-rabbit immune-globulin $G$ peroxidase conjugate (SIGMA A-6154). Finally, membranes were visualized using nitroblue tetrazolium/5-bromo-4-chloroindol-3-yl phosphate staining or SuperSignal West Pico (Thermo product number 34077).

For ELISA, proteins extracted using $0.05 \mathrm{M}$ carbonate buffer, pH 9.6, were coated onto Greiner 96-well plates for $3 \mathrm{~h}$ at $37^{\circ} \mathrm{C}$. Protein in the wells was incubated with anti-HCRSV antibody for $2 \mathrm{~h}$ at $37^{\circ} \mathrm{C}$, followed by secondary antibody alkaline phosphatase-conjugated protein A. Finally, freshly prepared $0.06 \%$ 4-nitrophenyl phosphate disodium salt hexahydrate (PNPP-NA2, 5 Primer and 3 Prime Inc., Gaithersburg, MD, U.S.A.) in $9.7 \%$ diethanolamine buffer was used for color development, and the absorbance number was read at a wavelength of $405 \mathrm{~nm}$ using a microplate reader (Tecan Infinite 200).

\section{Electron microscopy and immuno-gold labeling of cysteine and GSH.}

Preparation of the sample for immuno-gold labeling of cysteine and GSH was performed with ultrathin sections on nickel grids. Samples from the youngest fully developed leaves were prepared as previously described (Zhang and Wong 2009). Anti-cysteine or anti-GSH was used as primary antibody followed by diluted $10 \mathrm{~nm}$ gold-conjugated secondary antibody. Finally, the grids were dried and stained with $2 \%$ (wt/vol) uranyl acetate and Reynold's lead citrate for 10 and $3 \mathrm{~min}$, respec- tively, then examined using an FEI TECNAT T12 electron microscope.

Following the published method (Holler et al. 2010), five to six samples from mock-inoculated and HCRSV-infected leaves were examined. The numbers of gold particles per square micrometer on 32 ultrathin sections containing cell structures of both chloroplasts and peroxisomes from 30 different cells were counted. The numbers were analyzed using a nonparametirc Kruskal-Wallis test. Statistical differences were determined at the 0.01 level of confidence.

\section{ACKNOWLEDGMENTS}

This work was supported by the National University of Singapore (NUS) research grant R-154-000-493-112. We thank V. B. Yap from the Department of Statistics and Applied Probability, NUS, for his advice in statistical analysis.

\section{LITERATURE CITED}

Amtmann, A., and Armengaud, P. 2009. Effects of N, P, K and S on metabolism: New knowledge gained from multi-level analysis. Curr. Opin. Plant Biol. 12:275-283.

Bashandy, T., Guilleminot, J., Vernoux, T., Caparros-Ruiz, D., Ljung, K. Meyer, Y., and Reichheld, J. P. 2010. Interplay between the NADPlinked thioredoxin and glutathione systems in Arabidopsis auxin signaling. Plant Cell 22:376-391.

Blake-Kalff, M. M. A., Hawkesford, M. J., Zhao, F. J., and McGrath, S. P. 2000. Diagnosing sulfur deficiency in field-grown oilseed rape (Brassica napus L.) and wheat (Triticum aestivum L.). Plant Soil 225:95-107.

Bloem, E., Riemenschneider, A., Volker, J., Papenbrock, J., Schmidt, A., Salac, I., Haneklaus, S., and Schnug, E. 2004. Sulphur supply and infection with Pyrenopeziza brassicae influence L-cysteine desulphydrase activity in Brassica napus L. J. Exp. Bot. 55:2305-2312.

Bloem, E., Haneklaus, S., and Schnug, E. 2005. Significance of sulfur compounds in the protection of plants against pests and diseases. J. Plant Nutr. 28:763-784.

Bork, C., Schwenn, J. D., and Hell, R. 1998. Isolation and characterization of a gene for assimilatory sulfite reductase from Arabidopsis thaliana. Gene 212:147-153.

Brunt, A. A., and Spence, N. J. 2000. The natural occurrence of Hibiscus chlorotic ringspot virus (Carmovirus; Tombusviridae) in aibika or bele (Abelmoschus manihot) in some South Pacific Island countries. Plant Pathol. 49:798-798.

Brychkova, G., Xia, Z., Yang, G., Yesbergenova, Z., Zhang, Z., Davydov, O., Fluhr, R., and Sagi, M. 2007. Sulfite oxidase protects plants against sulfur dioxide toxicity. Plant J. 50:696-709.

Campbell, E. B., Hayward, M. L., and Griffith, O. W. 1991. Analytical and preparative separation of the diastereomers of L-buthionine (SR)-sulfoximine, a potent inhibitor of glutathione biosynthesis. Anal. Biochem. 194:268-277.

Dekok, L. J., Dekan, P. J. L., Tanczos, O. G., and Kuiper, P. J. C. 1981. Sulfate induced accumulation of glutathione and frost-tolerance of spinach leaf tissue. Physiol. Planta 53:435-438.

Foyer, C. H., and Noctor, G. 2009. Redox regulation in photosynthetic organisms: Signaling, acclimation, and practical implications. Antioxid. 
Redox Signal. 11:861-905.

Frottin, F., Espagne, C., Traverso, J. A., Mauve, C., Valot, B., LelargeTrouverie, C., Zivy, M., Noctor, G., Meinnel, T., and Giglione, C. 2009. Cotranslational proteolysis dominates glutathione homeostasis to support proper growth and development. Plant Cell 21:3296-3314.

Griffith, O. W., and Meister, A. 1979. Potent and specific inhibition of glutathione synthesis by buthionine sulfoximine (S-n-butyl homocysteine sulfoximine). J. Biol. Chem. 254:7558-7560.

Gullner, G., Tobias, I., Fodor, J., and Komives, T. 1999. Elevation of glutathione level and activation of glutathione-related enzymes affect virus infection in tobacco. Free Radic. Res. 31 (Suppl.):S155-161.

Hansch, R., Lang, C., Rennenberg, H., and Mendel, R. R. 2007. Significance of plant sulfite oxidase. Plant Biol. 9:589-595

Harms, K., von Ballmoos, P., Brunold, C., Hofgen, R., and Hesse, H. 2000. Expression of a bacterial serine acetyltransferase in transgenic potato plants leads to increased levels of cysteine and glutathione. Plant J. 22:335-343

Hesse, H., Kreft, O., Maimann, S., Zeh, M., and Hoefgen, R. 2004. Current understanding of the regulation of methionine biosynthesis in plants. J. Exp. Bot. 55:1799-1808.

Hirai, M. Y., and Saito, K. 2004. Post-genomics approaches for the elucidation of plant adaptive mechanisms to sulphur deficiency. J. Exp. Bot. 55:1871-1879.

Hirai, M. Y., Fujiwara, T., Awazuhara, M., Kimura, T., Noji, M., and Saito, K. 2003. Global expression profiling of sulfur-starved Arabidopsis by DNA macroarray reveals the role of O-acetyl-1-serine as a general regulator of gene expression in response to sulfur nutrition. Plant J. 33:651663.

Holler, K., Kiraly, L., Kunstler, A., Muller, M., Gullner, G., Fattinger, M., and Zechmann, B. 2010. Enhanced glutathione metabolism is correlated with sulfur-induced resistance in Tobacco mosaic virus-infected genetically susceptible Nicotiana tabacum plants. Mol. Plant-Microbe Interact. 23:1448-1459.

Huang, M., Koh, D. C. Y., Weng, L. J., Chang, M. L., Yap, Y. K., Zhang, L., and Wong, S. M. 2000. Complete nucleotide sequence and genome organization of Hibiscus chlorotic ringspot virus, a new member of the genus Carmovirus: Evidence for the presence and expression of two novel open reading frames. J. Virol. 74:3149-3155.

Jez, J. M., Cahoon, R. E., and Chen, S. 2004. Arabidopsis thaliana glutamate-cysteine ligase: Functional properties, kinetic mechanism, and regulation of activity. J. Biol. Chem. 279:33463-33470.

Kataoka, T., Hayashi, N., Yamaya, T., and Takahashi, H. 2004. Root-toshoot transport of sulfate in Arabidopsis. Evidence for the role of SULTR3;5 as a component of low-affinity sulfate transport system in the root vasculature. Plant Physiol. 136:4198-4204.

Kiraly, L., Kunstler, A., Holler, K., Fattinger, M., Juhasz, C., Muller, M., Gullner, G., and Zechmann, B. 2011. Sulfate supply influences compartment specific glutathione metabolism and confers enhanced resistance to Tobacco mosaic virus during a hypersensitive response. Plant Physiol. Biochem. doi:10.1016/j.plaphy.2011.10.020. Published online.

Kopriva, S. 2006. Regulation of sulfate assimilation in Arabidopsis and beyond. Ann. Bot. 97:479-495.

Kopriva, S., Mugford, S. G., Matthewman, C., and Koprivova, A. 2009. Plant sulfate assimilation genes: Redundancy versus specialization. Plant Cell Rep. 28:1769-1780.

Koprivova, A., Mugford, S. T., and Kopriva, S. 2010. Arabidopsis root growth dependence on glutathione is linked to auxin transport. Plant Cell Rep. 29:1157-1167.

Kumaran, S., Yi, H., Krishnan, H. B., and Jez, J. M. 2009. Assembly of the cysteine synthase complex and the regulatory role of protein-protein interactions. J. Biol. Chem. 284:10268-10275.

Leustek, T., Martin, M. N., Bick, J. A., and Davies, J. P. 2000. Pathways and regulation of sulfur metabolism revealed through molecular and genetic studies. Annu. Rev. Plant Physiol. Plant Mol. Biol. 51:141-165.

Li, S. C., and Chang, Y. C. 2002. First report of Hibiscus chlorotic ringspot virus in Taiwan. Plant Pathol. 51:803-803.

Marty, L., Siala, W., Schwarzlander, M., Fricker, M. D., Wirtz, M., Sweetlove, L. J., Meyer, Y., Meyer, A. J., Reichheld, J. P., and Hell, R. 2009. The NADPH-dependent thioredoxin system constitutes a functional backup for cytosolic glutathione reductase in Arabidopsis. Proc. Natl. Acad. Sci. U.S.A. 106:9109-9114.

Meng, C., Chen, J., Peng, J., and Wong, S. M. 2006. Host-induced avirulence of Hibiscus chlorotic ringspot virus mutants correlates with reduced gene-silencing suppression activity. J. Gen. Virol. 87:451-459.

Mugford, S. G., Yoshimoto, N., Reichelt, M., Wirtz, M., Hill, L., Mugford, S. T., Nakazato, Y., Noji, M., Takahashi, H., Kramell, R., Gigolashvili, T., Flugge, U. I., Wasternack, C., Gershenzon, J., Hell, R., Saito, K., and Kopriva, S. 2009. Disruption of adenosine-5'-phosphosulfate kinase in Arabidopsis reduces levels of sulfated secondary metabolites. Plant Cell 21:910-927.

Nikiforova, V. J., Bielecka, M., Gakiere, B., Krueger, S., Rinder, J., Kempa, S., Morcuende, R., Scheible, W. R., Hesse, H., and Hoefgen, R. 2006. Effect of sulfur availability on the integrity of amino acid biosynthesis in plants. Amino Acids 30:173-183.

Noctor, G., Gomez, L., Vanacker, H., and Foyer, C. H. 2002. Interactions between biosynthesis, compartmentation and transport in the control of glutathione homeostasis and signalling. J. Exp. Bot. 53:1283-1304.

Parmar, S., Buchner, P., and Hawkesford, M. J. 2007. Leaf developmental stage affects sulfate depletion and specific sulfate transporter expression during sulfur deprivation in Brassica napus L. Plant Biol. 9:647-653.

Rausch, T., and Wachter, A. 2005. Sulfur metabolism: A versatile platform for launching defence operations. Trends Plant Sci. 10:503-509.

Renosto, F., Patel, H. C., Martin, R. L., Thomassian, C., Zimmerman, G., and Segel, I. H. 1993. ATP sulfurylase from higher plants: Kinetic and structural characterization of the chloroplast and cytosol enzymes from spinach leaf. Arch. Biochem. Biophys. 307:272-285.

Rouached, H., Berthomieu, P., El Kassis, E., Cathala, N., Catherinot, V., Labesse, G., Davidian, J. C., and Fourcroy, P. 2005. Structural and functional analysis of the C-terminal STAS (sulfate transporter and antisigma antagonist) domain of the Arabidopsis thaliana sulfate transporter SULTR1.2. J. Biol. Chem. 280:15976-15983.

Saito, K. 2004. Sulfur assimilatory metabolism. The long and smelling road. Plant Physiol. 136:2443-2450.

Schnug, E., Haneklaus, S., Borchers, A., and Polle, A. 1995. Relations between sulfur supply and glutathione and ascorbate concentrations in Brassica napus. Z. Pflanzenernaehr. 158:67-69.

Smith, F. W., Ealing, P. M., Hawkesford, M. J., and Clarkson, D. T. 1995. Plant members of a family of sulfate transporters reveal functional subtypes. Proc. Natl. Acad. Sci. U.S.A. 92:9373-9377.

Takahashi, H. 2010. Regulation of sulfate transport and assimilation in plants. Inter. Rev. Cell. Mol. Biol. 281:129-159.

Takahashi, H., Yamazaki, M., Sasakura, N., Watanabe, A., Leustek, T., Engler, J. A., Engler, G., Van Montagu, M., and Saito, K. 1997. Regulation of sulfur assimilation in higher plants: A sulfate transporter induced in sulfate-starved roots plays a central role in Arabidopsis thaliana. Proc. Natl. Acad. Sci. U.S.A. 94:11102-11107.

Takahashi, H., Watanabe-Takahashi, A., Smith, F. W., Blake-Kalff, M. Hawkesford, M. J., and Saito, K. 2000. The roles of three functional sulphate transporters involved in uptake and translocation of sulphate in Arabidopsis thaliana. Plant J. 23:171-182.

Takahashi, H., Kopriva, S., Giordano, M., Saito, K., and Hell, R. 2011. Sulfur assimilation in photosynthetic organisms: Molecular functions and regulations of transporters and assimilatory enzymes. Annu. Rev. Plant. Biol. 62:157-184.

Tang, J., Elliott, D. R., Quinn, B. D., Clover, G. R. G., and Alexander, B. J. R. 2008. Occurrence of Hibiscus chlorotic ringspot virus in Hibiscus spp. in New Zealand. Plant Dis. 92:1367-1367.

Wachter, A., Wolf, S., Steininger, H., Bogs, J., and Rausch, T. 2005. Differential targeting of GSH1 and GSH2 is achieved by multiple transcription initiation: Implications for the compartmentation of glutathione biosynthesis in the Brassicaceae. Plant J. 41:15-30.

Watanabe, M., Hubberten, H. M., Saito, K., and Hoefgen, R. 2010. General regulatory patterns of plant mineral nutrient depletion as revealed by serat quadruple mutants disturbed in cysteine synthesis. Mol. Plant 3:438-466.

Waterworth, H. E., Lawson, R. H., and Monroe, R. L. 1976. Purification and properties of hibiscus chlorotic ringspot virus. Phytopathology 66:570-575.

Wirtz, M., and Hell, R. 2007. Dominant-negative modification reveals the regulatory function of the multimeric cysteine synthase protein complex in transgenic tobacco. Plant Cell 19:625-639.

Wykoff, D. D., Davies, J. P., Melis, A., and Grossman, A. R. 1998. The regulation of photosynthetic electron transport during nutrient deprivation in Chlamydomonas reinhardtii. Plant Physiol. 117:129-139.

Yi, H., Galant, A., Ravilious, G. E., Preuss, M. L., and Jez, J. M. 2010. Sensing sulfur conditions: Simple to complex protein regulatory mechanisms in plant thiol metabolism. Mol. Plant 3:269-279.

Yonekura-Sakakibara, K., Ashikari, T., Tanaka, Y., Kusumi, T., and Hase, T. 1998. Molecular characterization of tobacco sulfite reductase: Enzyme purification, gene cloning, and gene expression analysis. J. Biochem. 124:615-621.

Zechmann, B., and Mueller, M. 2008. Effects of zucchini yellow mosaic virus infection on the subcellular distribution of glutathione and its precursors in a highly tolerant Cucurbita pepo cultivar. Botany 86:10921100 . 